\title{
NOTES
}

\section{"Entry" Effective in Law to Toll the Running of the Statute of Limitations in Favor of Adverse Possessors}

Fairly definite concepts obtain as to the nature of the original entry on land requisite to set in motion the Statute of Limitations in the favor of an adverse possessor. Generally speaking, too, it has long been assumed that the running of the statute in favor of the adverse possessor may be interrupted by an "entry" ", or a "re-entry"-as it has sometimes been termed-2, before the expiration of the statutory period. But the legal incidents of this remedy of self-help have been uncertain. Who may "enter"? Where must the "entry" be made? Must the adverse possessor have knowledge or at least notice of the "entry"? What acts, what mental state, does "entry" involve? These are significant questions. But the question also arises whether the term "entry" has any useful meaning. Analysis of the statements of judges and text-writers on this real property concept of self-help may perhaps clear the uncertainty.

\section{Who May "Enter"?}

Judges and text authorities have often said that the "entry" must be "connected with a right to enter". . Obviously, then, the "entry" tol toll the statute could best be made personally by the one having the right of entry." However, the language of numerous cases and text authorities indicates that an owner may enter even by an agent ${ }^{5}$ or servant. ${ }^{6}$ And the orthodox interpretation of Hinman v. Cranmer ${ }^{7}$ is that an unauthorized entry on behalf of the owner may be ratified by him, making it the equivalent of a previously authorized entry. ${ }^{8}$ Logical extensions would seem to include entry to toll the statute by licensees of the record owner of land, ${ }^{9}$ by the owner's tenants who occupy in his behalf claiming

I. 2 Tiffany, The Law of Real Property and Other Interests in Land (ig20) \$ 507; 3 Thompson, Commentaries on the Modern LaW OF Real Property (1924) § 2530.

2. Sedgwick and Wait, A Treatise on the Trial of Titse to Land (2d ed. 8886 ) \$74I; Helm, Adverse Possession (1924) 8 MARQ. L. REv. 104, II4. Though nowhere is it expressly stated, it would seem that this variation in terminology has its basis in an attempt to differentiate more clearly between the adverse possessor's entry which starts the running of the statute in his favor and the effective entry of the true owner or some one in his behalf which stops the running of the statute in favor of the adverse possessor.

3. Trickett, The Law of Limitations of Actions in Pennsydvanta (i888) $\$$ i17.

4. 2 C. J. $\$$ II 3 and cases cited therein at n. 45.

5. Ingersoll v. Lewis, II Pa. 2 I2 (1849) ; Peabody v. Hewett, 52 Me. 33 (I86I) ; TIEDEMan, AN Elementary Treatise on the American LaW of Real Property (2d ed. I892) \$703; 2 TiffanY, op. cit. supra note I, \$ 507, at 1956, n. I5; 3 Thompson, loc. cit. supra note I; cf. Hollingsworth, Disseisin and Adverse Possession (I89I) 32 CENT. L. J. 140, 145.

The authority given to the agent by the owner to enter may be parol. Johnston v. Fitzgeorge, 50 N. J. L. 470, 14 Atl. 762 (Sup. Ct. I888). And, according to TRICKETT, loc. cit. supra note 3. "This authority may be affirmatively shown, and the declaration of the person while making it [the entry], that he was authorized, is not, ipso facto, proof thereof."

6. Johnston v. Fitzgeorge, 50 N. J. L. 470, 14 Atl. 762 (Sup. Ct. 1888) semble (the ministerial acts involved, - taking down separating fence, cleaning up premises, leveling off surface of ground, strewing ashes, - seem in keeping with a servant's tasks, rather than an agent's); cf. Camp v. Camp, 88 Vt. II9, 92 Atl. 12 (I914).

7. 9 Barr 40 (Pa. I848).

8. Cf. Campbell v. Wallace, I2 N. H. 362 (184I); Note (I84I) 37 AMr. DEc. 225.

9. Cook v. Easterling, 259 S. W. 1089 (Tex. Civ. App. 1924); see Howell v. Garlington, 270 S. W. 269, 270 (Tex. Civ. App. 1925). 
under him, ${ }^{10}$ by the holder of an equitable title bond to the land, ${ }^{11}$ by one of several heirs, ${ }^{12}$ and by one of several tenants in common. ${ }^{13}$ And so, where the owner of land adversely held has purported to convey his right of entry, subsequent entry by the grantee is-necessarily, under the old rule prohibiting transfer of that right ${ }^{14}$-no more than entry as a licensee or agent of the disseisee.

On the other hand, the intrusions of trespassers, it is said, "15 "if unknown, will not affect the possession $;^{16}$ but if known and repeated, without legal proceedings being instituted (by the adverse possessor), . . . become legitime interruptiones. . . ."

Thus, these rules on "who may enter" seem to have developed altogether on logic, without analysis as to the practical desirability of employing self-help.

\section{Where Must the "Entry" Be Made?}

Of necessity, in the logical view of the writers, an "entry" that tolls the statute must be upon the land adversely held, 17 although a "true entry" on any part of the land can rightly be considered an entry on the whole. ${ }^{18}$ Where there are several adverse possessors of distinct tracts, "effective entry" must of course be made against each, ${ }^{19}$ and when the land adversely occupied is situated in two or more counties, "effective entry" must be made on the parcel lying in each county, even though the whole tract is adversely possessed by but one person. ${ }^{20}$

10. Cf. Theriot v. Bollinger, 134 So. 372 (La. I93I) ; Winlock v. Gallaspy, r40 So. 846 (La. App. 1932) semble ( $G$ gathered pecans for owner, but rented land as tenant of both owner and adverse possessor's grantor); Cook v. Easterling, 259 S. W. 1089 (Tex. Civ. App. 1924).

II. Cf. Blakeley v. Pitman Coal Co., 19 Ky. L. I8Io, 44 S. W. 447 (1898).

12. Cf. Nelson v. Johnson, I8g Ky. 815, $226 \mathrm{~S}$. W. 94 (1920).

13. Gree v. Rolle, I Ld. Raym. 7 I6 (K. B. I702) ; ANgell, A Treatise on the LimitaTIONS OF Actions at Law AND SUITS IN EQUiTy AND AdMIRALTY (6th ed. 1876) \$379 at 382 ; $c f$. Carothers v. Dunning, 3 S. \& R. 373 ( $\mathrm{Pa}$. 1817) ("The entry of the agent appointed by one co-tenant will inure to the benefit of all, as would that of his principal." TRICKETT, op. cit. supra note $3, \S I \times 5)$.

14. "Rights of entry are not devisable . . . at common law, although they may be by statute." BURDICK, HANDBOOK OF THE LAW OF REAL PROPERTY (IgI4) 652.

But, "A grantee who knows of the adverse possession may yet get title by relation under his deed if it was executed in pursuance of a binding contract entered into before there was any adverse possession." Costigan, The Conveyance of Lands by One Whose Lands Are in the Adverse Possession of Another (I906) I9 HARv. L. REv. 267, 284; Steeple v. Downing, 60 Ind. 478 (1878); Jones v. Gaddis, 67 Miss. 76r, 7 So. 489 (I89o).

15. Doe v. Eslava, II Ala. I028 (I847); 2 Wood, A TrEatise on the Limitation of Actions AT LAW AND IN EQUiTY (4th ed. I9i6) \$270, n. 86.

I6. Bell v. Denson, 56 Ala. 444 (1876); Note (1923) 22 A. L. R. I458; Tindenan, $o p$. cit. supra note $5, \$ 714$ at 672 .

17. E. g., Pender v. Jones, 3 N. C. 463 (2 Hayw. 1803).

I8. Wickes v. Wickes, $98 \mathrm{Md}$. 307, 56 Atl. Ior7 (I924) ; 3 WASHBURN, A TREATISE oN the AMIERICan Law of Real Property (6th ed. I902) \$ 1957; $c f$. Helm, sipra note 2, at 114: "The essentials of an entry effective to break an adverse possession will vary according to the character of the premises involved"; Great Western Ry. v. Lutz, 32 U. C. C. P. I66 (I88r). It has been said that "An entry is thus operative because, although at the moment there exists in fact a mixed possession, the statute is stopped by virtue of the superior right of the owner." 3 THOMPSON, op. cit. sippra note $\mathrm{I}$, \$2530, at 652 . But $c f$. TrRcKET, op. cit. stupra note 3, § II6; Bordwell, Disseisin and Adverse Possession (Ig23) 33 YALE L. J. I, 2.

I9. Pender v. Jones, 3 N. C. 463 (2 Hayw. I803); Miller v. Shaw, 7 S. \& R. I29 (Pa. 182r) ; see Lawrence v. Hunter, 9 Watts 64,80 ( $\mathrm{Pa}$. I839).

20. Hord v. Walker, 5 Litt. 22, 23 (Ky. I824). The reason given is that "whenever a person has been ousted of his possession, it is a settled rule, that to regain the possession by entry, the entry must pursue the action for its recovery." Cf. Nearhoff v. Addleman, 3I Pa. 279 ( 1858 ), discussed in TRICKETT, op. cit. supra note 3 , § II6, at I54, 1 . 5; ANGEr, $o p$. cit. supra note $13, \$ 377$, at 382 : ". : Dut if the whole be in one county, an entry, with a declaration in the name of the whole, is sufficient." 
And of course, the bar of the statute is not tolled by an entry into an adjoining tract owned by the disseisee, but not itself adversely occupied. ${ }^{21}$

However, confusion creeps into the doctrine where the owner enters upon land held in constructive adverse possession only. The more heavily supported view in such case is that the entry is effective only as to the land in constructive adverse possession, ${ }^{22}$ despite some language to the effect that an entry on any part of the land will interrupt the adverse possession as to the whole. ${ }^{23}$ The majority idea is undoubtedly consistent with the old policy of favoring the adverse possessor by "quieting men's"-that is, adverse possessors'-estates. ${ }^{24}$

Difficulty also exists where the land in actual and constructive adverse possession is a portion of a larger tract whose owner makes re-entry outside the bounds defined in the worthless deed but within the borders of his land. Such entry is said not to affect the adverse possession. ${ }^{25}$

The above are but few of the logical ramifications of this doctrine of selfhelp as applied to the question "where must the entry be made".

\section{Must the Adverse Possessor Have Knowledge or at Least Notice of the "Entry"?}

A formulation of any balanced scheme centered about the idea of an "entry" effective to toll the statute must needs include the requirement that the adverse possessor should have knowledge or at least notice of the owner's "entry", if only, it is said, because "entry" to set in motion the statute required notoriety. ${ }^{26}$ But the problem of knowledge or notice in the case of constructive adverse possession gives considerable difficulty to the judges and writers. Where the "entry" is on land held in constructive adverse possession, Trickett has said : ${ }^{27}$

"Not residing nor clearing over upon the land, the latter [adverse possessor] has left no indication upon it of his identity. . . . The owner in making entry, was not bound to hunt after him. . . ."

On the other hand,

". . . when the adverse holder resides on the owner's land, or extends his fields over upon it, it would be necessary that he should have notice of the entry, when fugitive in character, and not such as would naturally arrest his attention, as it is, $e . g$., when the entry is for making a survey. The entry must be of such a character and accompanied by such notice as clearly indicate to the occupant that his possession is invaded and his right challenged." 28

2I. Carson v. Burnett, I Dev. \& Batt. 546 (N. C. I836).

22. Hunnicutt v. Peyton, IO2 U. S. 333 (I880); Creech v. Jones, 5 Sneed ( 37 Tenn.) 63I (I858); Freedman v. Bonner, 40 S. W. 47 (Tex. Civ. App. I897); see Wickliffe v. Ensor, 9 B. Monr. 253, 259 (Ky. I848); cf. McLean v. Smith, I06 N. C. I72, II S. E. I84 (I890).

23. Altemus v. Long, 4 Barr 254 ( $\mathrm{Pa} .1846$ ) ; see Smith v. Steele, I7 'Pa. 30, 33 (I851). TRICKETr, op. cit. supra note $3, \S$ II6, at I54, n. 4, says that these two cases seem to hold "that an entry anywhere within the owner's tract, even beyond its interference with a junior tract (a fortiori, if within that interference), would displace even the pedal possession of the owner of the junior tract." Cf. Adams v. Robinson, 6 Pa. 271 (1847); Taylor v. Burnsides, I Gratt. 165, I80 (Va. 1844) (argument of counsel).

24. Is the policy different in jurisdictions with recording systems?

25. Jones v. Gaddis, 67 Miss. 761, 7 So. 489 (I890); Stull v. Rich Patch Iron Co., 92 Va. 253, 23 S. E. 293 (1895); cf. Taylor v. Burnsides, I Gratt. I65, 178, I79 (Va. 1844) (argument of counsel) ; Sims, The Constructive Possession of a Claimant by Adverse Possession (1899) 4 VA. L. REG. 557 at 567 . And see note 24 supra.

26. Hoban, Adverse Possession (I913) 76 CENT. L. J. $39 \mathrm{I}$ at $394 ; 3$ Thompson, op. cit. supra note I, $\$ 2529$, at 65 I.

27. Op. cit. supra note 3 , § II8, at I57, citing Hinman v. Cranmer, 9 Barr 40 ( $\mathrm{Pa}$. I848).

28. Cf. AngeLl, op. cit. supra note $13, \S 378$, at 382 ; TRICKETT, op. cit. note 3 , $\$$ II8, at 158 ; Hoban, supra note 26 , at 394 . 
At any rate, there is abundance of expression that the owner's "entry" cannot be "stealthy", 20 "secret", made "openly" 32 or with a "reassertion of notorious dominion": 33

"The necessary purpose being clear, if the element of notoriety is sufficient to bring the situation home to the attention of the adverse occupant, if he is paying such heed to his possession as a person under the circumstance would ordinarily pay, that is sufficient." 34

There is also language that the "entry" of the owner must be either known to the adverse possessor ${ }^{35}$ or "be made under such circumstances as to enable the party in possession, by the use of reasonable diligence to ascertain the right and claim of the party making the entry". ${ }^{36}$ Yet, it is conceded, if the owner's acts on "entry" are of such a nature as to afford reasonable notice of claim of ownership, it is not necessary that the adverse claimant should have had actual knowledge thereof." As the court in Batchelder $v$. Robbins" ${ }^{38}$ put it: "It would be a task of great difficulty, and in most cases practically impossible, for a land-owner to prove such actual knowledge."

\section{What Acts Does "Entry" Involve?}

It is natural for the judges and text-writers to say that the acts involved in an effective entry necessarily depend on the circumstances of each case. ${ }^{39}$ And it is equally natural for them to add that closely connected with these acts is the intention which they evidence." ${ }^{40}$ Statements like the following abound: "[the owner] must assert his claim to the land, perform some act that would reinstate him in possession, before he can regain what he has lost." 41

29. Burrows v. Gallup, 32 Conn. 493 (I865) ; Tyler, A Treatise on the Rearedy by EJeCTMENT AND tHe LaW OF AdVERSE ENJOYMENT IN THE UNITEd STATES (I870) 908.

30. McCombs v. Rowan, $59 \mathrm{~Pa}$. 4I4 (I868) ; Helm, supra note 2, at II5: "Re-entry of mere casual or secret character will not interrupt an adverse possession."

31. Burrows v. Gallup, 32 Conn. 493 (1865); Batchelder v. Robbins, 93 Me. 579, 45 At1. 837 (Ig00); cf. Hollingsworth, supra note 5 , at I45; TIEDEMAN, op. cit. supra note $5, \$ 703$, at 668 .

32. 2 TIFFANY, op. cit. supra note I, § 507, at I955; 2 Wood, op. cit. supra note $15, \S 270$, at $\mathrm{I} 304 ; c f$. Worssam v. Vandenbrande, I7 W. R. 53 (C. P. I868).

33. Nelson v. Johnson, $189 \mathrm{Ky} .815,226 \mathrm{~S}$. W. 94 (1920) ("notorious acts of dominion"); Altemas v. Campbell, 9 Watts 28 (Pa. I839); cf. Note (I849) 5 I Axr. Dec. 539; Enslow, Adverse Possession (I9I8) II LAwY. \& B. 335 at 342 ; ANGELL, op. cit. supra note I3, at 430, n. I; SEDGWICK AND WAIT, op. cit. supra note 2, $\$ 742$, at 589 ("open and hostile act of dominion").

34. Enslow, supra note 33 , at 342 .

35. Wing, Adm'r v. Hall, 47 Vt. I82 (I874); 3 WASHBURN, op. cit. supra note I8, $\S 1957$ ("notice as clearly to indicate to the one in possession that this possession is invalid").

36. Home Iand Co. v. Nye, 93 Pa. Super. 452 (I928) ; Wing, Adm'r v. Hall, 47 Vt. I82 at 2r7 (IS74) ; Camp v. Camp, 88 Vt. II9, 92 Atl. I2 (I9I4). I2I (I88I)

37. Batchelder v. Robbins, 93 Me. 579, 45 Atl. 837 (Ig00) ; cf. Bowen v. Guild, r3o Mass.

38. 93 Me. 579 at 586,45 Atl. 837 at 840 (1900).

39. ". . . "we have and can have no exact definition of what a disseised owner must do in the way of reclaiming his property in order to interrupt the running of the statute'." Enslow, supra note 33, at 342 . Cf. O' Hara v. Richardson, 46 Pa. 385 (I863); TRICKETT, op. cit. supra note 3, § I17; Burgoyne, Title by Adverse Possession (1913) 6 LAwy. \& B. I97, $20 \mathrm{I}$.

40. TRICKETT, op. cit. supra note 3 , § Ix7: "The act ('an act of notorious dominion') may, in its very nature, show the purpose or intent with which it is done, in which case any declaration of its purpose at the time would be superfiuous, or being ambiguous in its nature, that nature may require illustrations by declaration of the party in making the entry."

4I. Burrows v. Gallup, 32 Conn. 493 at 499 (I865); Tyler, op. cit. supra note 29, at 908; 2 WoOD, op. cit. supra note $\mathrm{I} 5, \$ 270$, at $\mathrm{I} 305$, and $\mathrm{n}$. 88 . 
Apparently, an owner to make an effective entry need not actually turn the adverse possessor out of possession. ${ }^{42}$ But just how unequivocal the act must be where re-entry is not by actual ouster seems highly disputed. ${ }^{43}$ For example, in England the Real Property Limitation Act of $1833^{44}$ provides: ". . . No Person shall be deemed to have been in Possession of any Land within the Meaning of this Act merely by reason of having made an Entry thereon."

In this country, according to Sedgwick and Wait : ${ }^{45}$

". . . the requisites for an effectual re-entry by the owner are the same as to establish an adverse possession in the case of an entry by a disseizor. That is to say the re-entry must be evidenced by distinct acts of ownership inconsistent with any adverse claim, and be made with the intent to claim the exclusive possession."

Nothing save the old policy of favoring the adverse possessor can justify a requirement that the owner's re-entry must satisfy all requirements for an adverse possessor's entry.

A discussion of the effect of the statutory modifications of "entry" on the acts involved will be made later.

\section{What Mental State Does "Entry" Involve?}

Great weight is given to the essential animus, sometimes stated to be the "unequivocal intent to resume actual possession", ${ }^{46}$ and more frequently stated to be the "animus clamandi". ${ }^{47}$ The latter expression is manifestly inadequate, since it does not describe the nature of the claim and since not every claim includes an intention to possess.

Though the expressions of the writers in framing a definition of the requisite animus have been inconsistent, it is at least agreed that when the owner's reentry upon his land is by accident, ${ }^{48}$ invitation, ${ }^{49}$ permission or assent, ${ }^{50}$ or to pay

42. SEDGWick AND WaIt, op. cit. supra note 2, §741, at 587. Cf. TIEDEMan, op. cit. supra note $5, \S 703$, where it is said: "A mere re-entry upon the land by the disseisee or by his authorized agent, with the intention to recover the seisin, is sufficient to regain the seisin, even though the disseisor is not actually expelled, since the joint-possession by them destroys the element of exclusiveness, necessary to disseisin." If "entry" be resumption of possession by the owner, theoretically this is incorrect, since at a single given time it is impossible for more than one person to be in possession of land or chattels. See TERRY, Some Leading Principles of ANglo-A Mierican Law Expounded with a View to its Arrangement and Codification (1884) 268.

43. Cf. Altemas v. Campbell, 9 Watts 28 (Pa. I839); Hollinshead v. Nauman, $45 \mathrm{~Pa}$. I40 (I863) (There must be something to show that a survey was made with the purpose of resuming possession unequivocally manifested.) ; ANGELL, op. cit. supra note 13 , at $430, \mathrm{n}$. I : "A single act of taking possession, and then leaving the land, will not do." But $\mathrm{cf}$. 3 THOMPSON, op cit. sipra note $1, \$ 2530$, at 652 , wherein it seems to be assumed that a single act of taking possession is sufficient, and the situation in which the "owner's entry is followed up by the owner's possession" is merely an a fortiori one. Note also the statement in Hoban, supra note 26 , at 394: "Thus an entry and occupation by the true owner regardless of the length of time is sufficient to break the holding." And see Robison v. Swett, 3! Me. 3I6 (1825).

44. $3 \& 4$ Wm. IV, c. $27, \S$ to (I833).

45. Op. cit. supra note 2 , \$ 74I.

46. Enslow, sipra note 33, at 342.

47. E. g., ANGELL, op. cit. supra note $13, \S 378$.

48. Hood v. Hood, $25 \mathrm{~Pa}$. 417 (I855); Caldwell v. Copeland, $37 \mathrm{~Pa} .427$ (1860); TRICKETT, op. cit. supra note $3, \S \mathrm{II} 7$, p. I54, n. 6.

49. Hood v. Hood, $25 \mathrm{~Pa}$ 4I7 (I855); ANGerL, op. cit. supra note 13, §378, citing Plowd. 82 ( $176 \mathrm{I}$ ): "Where . . a party by invitation of the tenant, went into a cellar to see its antiquity, it was adjudged to be no such entry as would vest the possession in the person so entering."; TRICKETT, op. cit. supra note 3 , \$ II 7 , at I54.

5o. Altemas v. Campbell, 9 Watts 28 ( $\mathrm{Pa}$. I839); cf. Nelson v. Johnson, I89 Ky. 8I5, 226 S. W. 94 (1920) (heirs given permission to cultivate single crop). 
a friendly visit to the adverse possessor ${ }^{51}$ the necessary mental state is lacking. Similarly, where the owner has entered under contract, ${ }^{52}$ or merely to inspect the condition of the land, ${ }^{53}$ or to determine if there is any adverse possession, ${ }^{54}$ or to make a survey merely to ascertain the locality of the land, ${ }^{55}$ such action does not interrupt the running of the statute. Mere casual crossing, in connection with the control of other land, of the land adversely held, ${ }^{56}$ or a mere physical entrance thereon, ${ }^{57}$ have likewise been said to be inoperative.

\section{Statement of Problem}

From these statements in the cases and treatises, everyone appears to have assumed the existence of an independent concept of "entry", and its effectiveness as a form of self-help to toll the running of the statute. But in truth, whether it has been deemed too obvious for statement or not, apparently "entry" is for this purpose synonymous with the resumption of possession by the owner. ${ }^{58}$ And yet possession itself is a legal concept which, despite the presence of at least one fairly acceptable definition, ${ }^{59}$ is extremely difficult to delimit. Taking "entry", then, to mean the regaining of possession by the owner without judicial aid, the court is confronted with the task of deciding-usually on evidence characterized by a paucity of facts, a necessity of interpreting facts of conduct, and contradictory evidence-who has possession, and ultimately whether the acts done shall terminate the running of the statute.

With this as the ultimate question, it is manifest that the court finds itself in the center of a conflict between ownership and possession ; in other words, will the law sanction the use of self-help by the owner against the adverse possessor?

Professor Maitland after asking, "Does the law protect possession against property?" proceeds : ${ }^{61}$

"If we were free to write history out of our own heads, it would be a plausible doctrine that gradually and steadily the right of a dispossessed owner to right himself, to take what is his own, is curtailed by law; that in the law of the later middle ages, the law of Littleton's time, we may see the first tentative and clumsy advances towards a protection of possession against ownership. But such a doctrine would be quite untrue; the sphere

5I. Williams v. McDonald, 33 U. C. Q. B. 423 (1873) ; Hartley v. Maycock, 28 Ont. 508 (I897); Brock v. Benness, 29 Ont. 468 (1899); McCowan v. Armstrong, 3 Ont. L. R. I00 (1902).

52. R. W. Wier Lumber Co. v. Eaves, 291 S. W. 337 (Tex. Civ. App. I927) (removal of timber under contract).

53. Bowen v. Guild, I30 Mass. I2I (I88I).

54. Ibid.; Batchelder v. Robbins, 93 Me. 579, 45 Atl. 837 (I900).

55. Hollinshead v. Nauman, 45 Pa. 140 (1863) ; Collins v. Benedict, 5 Luz. Leg. Reg. Iog (Pa. I876); $c f$. McCombs v. Rowan, 59 Pa. $4 \mathrm{I4}$ (I868).

56. Home Land Co. v. Nye, $93 \mathrm{~Pa}$. Super. 452 (1928).

57. Burrows v. Gallup, 32 Conn. 493 (1865); Ahern v. Travelers' Ins. Co., I08 Conn. I, 142 Atl. 400 (Ig28); $c f$. Doe v. Coombes, 9 C. B. $7 I_{4}$ (1850); Lightwood, A Treatise oN Possession OF LAND (I894) 265.

58. Cf. Ligntwoon, op. cit. supra note 57 , at 268 : "The statute . . is checked . . . when the owner by re-entry resumes the actual possession. . . " And see TrickerT, op. cit. supra note $3, \S \mathrm{II} 5$, at I53, n. 4: "If the adverse holder vacates the possession, he stops the running of the statute, partly because it is more than doubtful whether the owner could make an entry to avoid the statute when there was none in possession to enter upon. Stephens v. Leach, 19 Pa. 262 (1852)."

59. TERRY, op. cit. supra note 42 , at 268 : Possession-“any power to use and exclude others, however small, will suffice, if accompanied by the animus possidendi, provided that no one else has also the animus possidendi and an equal or greater power." This was approved by Pollock and Wrighr, An Essay on Possession in the Common Law (I888) I3.

6o. Maitland, The Beatitude of Seisin, II (I888) 4 L. Q. REv. 286.

6r. Maitland, The Beatitude of Seisin, I (r888) 4 L. Q. REv. 26. 
allowed to self-help by the law of the twelfth century is almost infinitely narrower than that allowed by the common law of the fifteenth."

His conclusion was that the law in Bracton's day "protects possession, untitled and even vicious possession," against property. ${ }^{62}$ This then, it seems, is the medieval policy which guards carefully the adverse possessor. The strife, disorder and lawlessness of the I200's coupled with the general desire for public peace furnished politic reasons for the rigid curtailment of self-help. But the passage of time, though perhaps not the passage of lawlessness, Maitland writes, reversed the answer which the law gave to his question: ${ }^{63}$

". . . in the days of Littleton . . . the common law does not protect possession against ownership, except in those comparatively rare cases in which there has been a descent cast or a discontinuance, one of those acts in the law (their number is very small) which have the effect of tolling an entry."

The remainder of this note will be devoted to a discussion of the typical American and English cases and statutes relating to "entry", keeping in mind the general doctrines above stated. The inferences to be deduced from any possible rationalization of the material will necessarily have a direct bearing on the fundamental conflict between ownership and possession. Judicial recognition or nonrecognition of self-help, as Maitland points out, is after all the ultimate solution of the conflict. And from the material, it will be seen, the tendency for the last century and more has apparently been to deny such recognition-to protect possession against ownership.

\section{American Cases}

A study of the English cases after adverse possession of land displaced disseisin reveals little foundation for the doctrine of "entry". On the other hand, the American cases and texts clearly disclose a theory, unjustified by the holdings of the cases, which makes the requirements for "entry" by the owner equivalent to those for "entry" by the adverse possessor. Examination of some of the American cases throws light on the shallow foundations of fact (so far as disclosed in the reports) upon which the doctrine rests.

Ingersoll v. Lewis, ${ }^{64}$ an early Pennsylvania decision, is often cited for the proposition that an owner may "enter" by an agent as well as in person. ${ }^{65}$ In that case owner $O$ brought an action of ejectment against $A$. $A$ admitted $O$ 's original title, defending exclusively on the ground of adverse possession of the land for the duration of the limitation period. In the course of the evidence it was shown that eleven years before the alleged entry, $A$ had (by written agreement) recognized $O$ 's title to the land. Later a surveyor whom $O$ hired surveyed the land. $O$ alleged this to be an effective entry by an agent. The lower court charged the jury that $A$ 's written agreement recognizing $O$ 's title was sufficient to preclude the possibility of adverse possession, but that the facts of the alleged entry were not sufficient to toll the statute. The upper court reversed because of error in the charge, setting forth in the opinion the dogma that an agent may enter, etc. The court concluded, however, by saying that in fact $A^{\prime}$ 's possession was never adverse. ${ }^{.8}$

62. Maitland, loc. cit. supra note 60.

63. Ibid.

64. II Pa. 2 I2 (I849)."

65. See TRICKETT, op. cit. supra note 3 , § II5. (I909).

66. For a somewhat similar case see Kipp v. Hagan, I08 Minn. 384, I22 N. W. 317 
Hinman v. Cranmer ${ }^{67}$ is an even more striking Pennsylvania decision illustrating the failure of courts to direct their analysis to the heart of the problem. $O$ brought ejectment against $A$, who "had the title to an adjoining tract, on which he resided, and claimed the land in question by virtue of an occupancy, without residence, for twenty-one years." It was proved that $O$ had given a power of attorney to $M$ to attend to the lands. $M$ employed $F$ to make a survey, which he did. $O$ set this up as an entry tolling the statute, having paid for the survey and having recognized $F$ 's act. The lower court considered that this entry saved $O$ 's right. On appeal, the judgment for $O$ was affirmed. From the language of the opinion the holding appears to be that $O$ 's subsequent ratification of the entry by the unauthorized agent was equivalent to previous command. ${ }^{68}$ And this is the proposition deduced by the writers as the principle of the case. The real clue to the decision lies in these words:

"Nothing which is the subject of evidence could be more strongly marked than the intent of the owner to resume actual possession in this case, if indeed he had ever been ousted, for he regularly paid his taxes for his full tract. But whether he was in fact or in law ousted or not, it is unnecessary to inquire, as the court is clear that the entry of the owner . . . barred the running of the statute." ${ }^{8}$

How can there be an "entry"-a retaking of possession-to toll the statute if there never was any adverse possession?

Discussion of another leading case can perhaps exhaust the typical American decision purporting to determine who may enter. In Johnston v. FitzGeorge ${ }^{70}$ matter was certified to the Supreme Court of New Jersey for its advisory opinion (!) in the trial of an action of ejectment. The sole question certified related to whether a directed verdict should have been given for $A$. $A$ 's defense against ejectment rested on adverse possession of the land for the statutory period. The premises in question consisted of a few square feet of land, situated nearly at the rear of a city lot in the heart of a city. The testimony disclosed that $O$ had directed a relative to take down a fence separating the allegedly adversely occupied tract from other of $O$ 's lands. This was done. Further, at $O$ 's direction the premises were "cleaned up", the surface of the ground was leveled, and ashes were spread on the land. At that time, which was within the statutory period, no structure other than the fence was found thereon. A week later the fence was replaced, apparently under the claim of adverse possession. The court declared that no directed verdict should have been given for $A$, but that the whole case should have been submitted to the jury. However, the court indulged in a lengthy discourse restating the dogmas concerning entry and who may enter, although (from the unsatisfactory report of the facts) it is doubtful that any adverse possession existed. Thus, the case is far from a square holding that the facts set forth constituted an entry effective to toll the statute. And yet it is generally conceded to be a leading American case on this doctrine, and particularly on the question who may enter.

An interesting case denying as a matter of law that $O$ 's acts constituted an entry is the early decision, Holtzapple v. Phillibaum." " $[O]$ had attended every year, prosecuting and claiming his title to the land adversely held by [ $A]$." A witness testified that he was with $O$ every year on the land, but he could not remember what $O$ had said when he was on the land. On this state of facts Jus-

67. 9 Barr 40 (Pa. 1848$)$.

68. Cf. Note (I84r) 37 AM. Dec. 225.

69. 9 Barr 40 at $42^{\prime}$ (Pa. I848). Italics supplied.

70. 50 N. J. L. 470 , I4 Atl. 762 (Sup. Ct. I888).

7r. 4 Wash. 356 (C. C. Pa. I823). 
tice Washington gave binding instructions that such an entry could not toll the statute. In the charge to the jury the following is to be noted: ${ }^{72}$

“. . . it will be proper to state to the jury what it is which constitutes a legal entry to avoid the bar of the act of limitations. . . Upon these subjects the law is perfectly clear. He must enter with intent to claim the possession; and he must do some act to prove that such was his intention, as by cutting a tree, digging the ground, or by other acts amounting to a trespass on the land, or he must declare that he enters for the purpose of claiming or taking possession. No particular form of words is prescribed by the law. The substantial part of the ceremony is the taking, or declaring an intention to take, or claim the possession."

Yet in the same charge, O's attending every year on the land, prosecuting and claiming his title to the land is held as a matter of law not to be an effective entry!

On the contrary, in Bozven v. Guild ${ }^{73} O$ did acts amounting to a "trespass on the land"; nevertheless, his entry was held ineffective. ${ }^{74}$ And no decision can be found in which $O$ 's cutting a tree, digging the ground or declaring that he enters for the purpose of claiming or taking possession is held to toll the statute. "The law is perfectly clear", rather, that there is a uniform refusal on the part of American courts to hold such acts by $O$ an effective entry: The centuries-old distinction between trespass and ouster, and consequently between the actions of trespass and ejectment, makes such refusal unavoidable.

In numerous cases the courts have found a conspicuous absence of the necessary mental state, and for that reason have held the statute uninterrupted. Thus, while in Borven $v$. Guild, ${ }^{75} \mathrm{O}$ and his attorney went upon the land (an act which certainly amounted to a "trespass on the land" within the meaning of Justice Washington's language) for the purpose of discovering, if they could, any evidence of adverse occupation upon which $O$ could bring a writ of entry against $A$, the absence of an intent to resume actual possession coupled with the lack of an "act of ownership" made the "entry" so questionable in the eyes of the Massachusetts Supreme Court that it was error for the trial judge to rule that the re-entry was an "interruption in fact of ( $A$ 's) possession". Additional examples would be only cumulative.

The tendency of courts to indulge in dicta on "entry" is best shown by cases containing statements that the adverse possessor must have notice at least of the "entry". It is well settled, of course, that notoriety is an essential element of the "entry" by the adverse possessor. Indeed, it would seem obvious under Terry's "control and animus" definition of possession ${ }^{76}$ that notoriety should follow from the fact that there is adverse possession. Possession being such a difficult fact-law conclusion to determine, at worst notoriety of control and animus constitutes valuable evidence to aid the judicial trier of the fact in reaching his result. The American cases, as was pointed out above, frequently employ this "notice" language. And the spaciousness of lands in America would be a factor tending to complicate the proof, were not an express requirement of notoriety as an integral element of "entry" indulged. But while the American cases reveal this language, the facts presented in these cases reveal little reason for its application therein.

72. Id. at 368. Italics supplied.

73. I30 Mass. I2I (I88I).

74. Quite properly, of course, since the law has always distinguished trespass from taking of possession.

75. I30 Mas. I2I (I88I).

76. Supra! note 42. 
For example, in the case of Burrowus v. Gallup, ${ }^{77}$ referred to over and over again by other decisions ${ }^{78}$ as well as by text-writers, ${ }^{79}$ adverse possession of land was not even involved, but only adverse user. On the other hand, Batchelder v. Robbins ${ }^{80}$ presents at least a more accurate background for the "notice" language, despite the court's reliance on the Burrowes decision in its opinion. Plaintiff $A$ brought writ of entry against defendant $O$ to establish title to certain land. $A$ claimed title by adverse possession under color of title. $O$ also claimed title by adverse possession under color of title. "The only question submitted to the jury was whether $[A]$ or $[O]$ had acquired title to the land by adverse possession." " $O 1$ asserted that the acts of possession testified to by $A$ were not sufficient in kind and character to give title by adverse possession, nor were they continued uninterruptedly for the limitation period. Evidence tended to show that during the period of $A$ 's "occupancy", several other persons cultivated and occupied parts of the land, especially $X$, allegedly a lessee of the man from whom $O$ derived his title. On this state of facts, the jury returned a general verdict for $A$, and a special verdict that he "had been in open, notorious, adverse, exclusive and uninterrupted possession" for the limitation period. Defendant $O$ had excepted to the charge of the lower court, which, inter alia, contained statements to the effect that actual knowledge by $A$ was necessary before any acts could be considered an interruption of the statute. The upper court sustained the exceptions because of this imposition of "too heavy a burden of proof" on $O$. "Reasonable notice", not "actual knowledge", was all that was necessary. Thus, under the facts, by sustaining $O$ 's exceptions the Maine Supreme Court is merely restating what it believes is the dogma which the trial court must follow in its charge to the jury on the retrial of the case, and is not deciding as matter of law that there was an "entry" with sufficient notoriety in Batchelder $v$. Robbins. The imperfection of the court's lengthy dissertation on the American authorities, case and text, wherein "entry" language appears, is indicated by the fact that Burrows v. Gallup was relied on to support these dicta.

In general, the few American cases discussed above present a fair crosssection of the typical decision to be found in the digests and texts where "entry" by the owner is the topic. No case has been found which squarely holds that $O$ 's "entry"--even in the sense of a resumption of possession-is sufficient to toll the running of the statute. Courts and text-writers have indulged in use of the label "entry" with little thought as to what appears to be the real issue, namely, whether the courts should sanction the use of self-help in the resumption of possession. Of necessity, such would be the effect of any decision that $O$ 's acts constitute an "entry", in that sense. Perhaps the explanation of this state of the authorities lies in the obviousness of the matter, perhaps in the fact that only the pathological case involving the problem reaches the courts, and that, in the last quarter or half century, cases involving "entry" have been exceedingly rare. ${ }^{82}$ At any rate, despite the readiness with which the judges set forth the generally accepted doctrines and thus apparently put their stamp of approval upon self-help, no actual cases have upheld an "entry", which is a strong indication

77. 32 Conn. 493 (1865).

78. E. $g$., see the striking quotation in Batchelder v. Robbins, $93 \mathrm{Me} .579,584,45$ Atl. 837,839 (1900). 79. E. g., see SEDGWICK AND WAIT, op. cit. supra note $2, \$ 74 \mathrm{I} ; 2$ Wood, op. cit. supra
note I5, \$270, n. 88 .

80. 93 Me. 579, 45 Atl. 837 (1900).

8I. Ibid.

82. $\mathrm{Mr}$. H. W. Chaplin, a most excellent authority, stated in I898: "in the older of the thickly settled communities [i. e., the Eastern States] the writ of entry is obsolete." (I898)
I2 HARv. L. REv. 3I. 
that judicial approval of this form of self-help is only verbal and that in fao: the judges actually disfavor it.

The historical background of early American life supplies some support to this view. The lawlessness which existed in Bracton's England ${ }^{83}$ can find a modern counterpart in the turbulent pioneer days of this country. The broad expanse of lands in the United States contributed to the difficulty of maintaining law and order. Thirteenth century lawmakers endeavored to check self-helpa right strongly tending to social disturbance-by introducing the Forcible Entry Act ${ }^{84}$ and the writ of Novel Disseisin. ${ }^{85}$ In similar fashion, it would seem, the American courts have shied away from granting judicial approval to an exercise of the non-judicial remedy, "entry", at the same time, paradoxically, being eager to talk in terms of "entry" where approval of this doctrine is not inherent in the result.

\section{English Cases}

The English courts and writers have approached the problem simply, in comparison with American. The influence of Coke, as Maitland's research has shown, ${ }^{86}$ contributed substantially to protecting ownership against possession even to the extent of keeping alive "mere formal entry" and continual claim. According to Maitland this view persisted well into the nineteenth century. But the First Report of the English Property Commissioners reveals a distinct change in attitude: ${ }^{87}$

"We are of opinion that nominal entries on land which do not change the possession should be of no avail to the claimant in extending the period of limitation . . . an entry without change of possession is generally a secret act; great doubts may arise respecting the proof of it in point of fact, and also as to what amounts to such an entry in point of law; and it seems better for both parties to require that within the prescribed period, either possession shall be openly taken by the claimant, upon which an action of trespass may immediately be brought against him; or, if he cannot obtain possession, that he should commence an action of ejectment to try the right."

This Report, leading to the Real Property Limitation Act of $1833^{88}$ caused the abolition of the doctrine of mere entry and continual claim. "The result", as Lightwood relates, "is that an entry, to vest the possession in the person entering and prevent the bar of the statute, must be effective as opposed to merely formal." Whether it be the rigorous nature of the Act, frowning, it appears, on "entry", or merely the fact that it is only the pathological case involving selfhelp which comes before the courts, the rarity of English cases involving re-entry after the Act of 1833 is extremely noticeable. Perhaps the explanation lies in: the impracticality of self-help by re-entry as compared with the efficient action of ejectment; the possibly strong, unspoken attitude against the remedy in view of the legislative expression; the scarcity of land in England as contrasted with this country - a factor tending to fewer absentee owners in England; or even the nature of the times-order and social repose being now the rule rather than the exception.

At any rate, it was not until seventeen years after the passage of the important Limitation Act of 1833 that a case of adverse possession and "entry"

83. Cf. Maitland, supra note 6o, at 29I ; I Bracton's Note Book (Maitland ed. 1887) 23.

84. 5 RIc. II, Stat. I, c. 7 (138I) ; cf. Maitland, supra note 6I, at 25 ; cited note 60 , at $29 \mathrm{I}$.

85. Maitland, supra note $6 \mathrm{I}$, at 26 et seq.

86. Maitland, sipra note 60 , at 289 ; cf. Co. LITT. $252 \mathrm{~b}$, cited over and over again by the American cases; 2 WOOD, op. cit. supra note 15, \$270, at 1307 .

87. FIRST REPORT 4I; see LIGHTWOOD, op. cit. supra note 57, at 264-265.

88. 3 \& 4 WM. IV, c. 27 ( I833).

89. Op. cit. supra note 57 , at 265 . 
appeared in the English reports. In Doe v. Coombes ${ }^{\circ 0}$ the lord of a manor brought ejectment for an acre of land, part of the waste of the manor with a hut erected thereon, which had been occupied without the permission of, and adversely to, the lord for considerably more than twenty years before the commencement of the action in 1850 . In 1835 , the lord of the manor, accompanied by his steward, had gone to the premises, and, finding the defendant's wife and family there, entered, stating that he took possession and directing that a stone should be taken out of the wall of the hut, and a portion of the fence inclosing the premises be removed. Then they retired. All this was done without any objection being made on the part of defendant $A$, who was not present at the time. Pursuant to a direction from the court, the jury determined that the lord had not done enough to acquire possession. On dismissing a rule to show cause why the verdict should not be entered for $O$, the court held that the acts done by the lord "clearly amounted to no more than an entry, which since the late statute is not enough to bar the tenant's right unless accompanied by circumstances which would restore the possession of the land to the lord." ${ }_{91}$ From this opinion it is apparent that the judges were more than willing to construe the Limitation Act of I833 very strictly against the owner. If the medieval policy be to favor the adverse possessor, the indication is from the Coombes case that this English statute has gone far in adopting this policy.

The case of Randall $v$. Stevens, ${ }^{92}$ decided in 1853 , is considered by Lightwood as illustrative of an effective re-entry by the owner, whereby the occupier is actually put out of possession. ${ }^{93}$ "The overseers of a parish entered upon a pauper who had been let into possession of a cottage, turned out himself and his family, and removed nearly the whole of his furniture. On the same day he resumed possession, but it was held that possession had been taken by the overseers, and that the statute had been checked." ${ }^{44}$ However, the report discloses, first, that though the case obviously does involve self-help by the landowners, it is not stated (though in truth the facts may suggest it) that there was adverse possession by the pauper. This appeared immaterial to the court, and the whole argument in behalf of $A$ had proceeded on the contention that $A$ was a tenant at will. Secondly, the case of Doe v. Coombes, ${ }^{95}$ which arose three years earlier, was not even cited or referred to by the court and counsel in the Stevens case. Certainly this case is a poor authority.

Worssam $v$. Vandenbrande ${ }^{96}$ is more in point. $O$ showing a paper title in himself brought ejectment against $A$, who claimed under the Statute of Limitations. $O$ disputed $A$ 's continuous possession, relying on an interruption which allegedly took place between nineteeen and twenty years before the action was brought. The interruption alleged, according to the reporter's statement, was of this character:

"[O] went to the land, and with implements which he had brought broke down the fence which enclosed the land, and erected a post on the close, to which he affixed a board, on which was painted a statement that anyone who desired to take a lease of the land should apply to ... [O]. At the time this was done the close was undoubtedly in $\left[A^{\prime} s\right]$ possession. But that possession was evinced solely by the fence. . . .

90. 9 C. B. 714 (1850) (recounted by LigHTwood, op. cit. supra note 57, at 266).
9I. Id. at 7I7.

92. 2 E. \& B. 641 (1853).

93. LIGHTwOod, op. cit. supra note 57 , at 266 .

94. Ibid.

95. 9 C. B. 714 (1850).

96. 17 W. R. 53 (C. P. 1868). [For a somewhat similar American case see Landon v. Townshend, I29 N. Y. 166, 29 N. E. 7 I (I89I).] 
"[O] remained on the land three-quarters of an hour. Three days after this the post and board were gone, but there was no evidence to show who had removed them, nor was there evidence of any subsequent dealing with the land by act thereupon by anyone for the next five years. After that period the possession of . . . $[A]$. . was evinced by acts of the most unequivocal kind-namely, by the erection of buildings.

"The sole question raised was whether the entry just described was a mere entry, or was such a dealing with the land as amounted to taking possession so as to interrupt the adverse possession." ${ }^{97}$

A verdict given for $O$ was permitted to stand, the court's terse and entire opinion being : ${ }^{98}$

... "There had been no adverse possession but the fence. When that was pulled down I cannot see that anything remained to make the possession of the defendant $[A]$. The case of . . . $[O] \ldots$ does not rest wholly on the pulling down the fence, and then erecting the post, but also on this, that there is no evidence from I 848 to I853 of any act on the land hostile to the title of the true owner. Doe v. Coombes seems to me to support the present view. The party was there in possession, and what was held there was that what was done was no divesting of possession . . .."

In light of the court's view that "there had been no adverse possession but the fence", the case may well be explained on the absence of any adverse possession, despite the reporter's conclusion that "the close was undoubtedly in $\left[A^{\prime} s\right]$ possession." Assuming, however, that $A$ was originally in adverse possession of the tract, of which the fence was evidence, the report leaves open the question whether the cessation of the adverse possession was caused by O's entry or $A$ 's abandonment. And if the latter be the case, which the court intimates, at best the Worssam case is authority to the effect that on abandonment of adverse possession, O's "constructive possession" is resumed.99

This can fairly be termed the state of the decisions in England since I833few and lacking in affirmative holdings on "entry". The rarity of the decisions has at least obviated the confusion which exists in the American cases. At the same time this scarcity gives rise to the thought that, in England too, the remedy of self-help by entry exists rather in the mind of the theorist than in the mind of the practicing lawyer who advises his client concerning his legal rights against the adverse possessor.

\section{Statutes}

In general, there are three different classes of statutory modifications of "entry",100-all of which are far more drastic than the English Real Property Limitation Act of I833: ${ }^{101}$ the most numerous type requires the "entry" to be followed by an action of ejectment; frequently others demand that the "entry" be followed by possession for a certain time; and a third type, Tiffany adds, ${ }^{102}$ "expressly deprives the entry of any . . . effect."

The Pennsylvania Act of April I3, I859 ${ }^{103}$ is a typical statute requiring "entry" to be followed by judicial process:

97. Ibid.

98. Id. at 54 .

99. LIGHTWOOD, op. cit. supra note 57 , at 268 .

100. 3 \& 4 WM. IV, c. 27 (1833).

IOI. See generally, SEDGWICK AND WAIT, op. cit. supra note $2, \S 742 ; 3$ Thompson, op. cit. supra note I, at $653 ; 2$ Wood, op. cit supra note I5, $\$ 270$.

102. 2 TIFFANY, op. cit. supra note I, $\$ 507$, at 1956 .

103. P. L. 603, \& I; PA. STAT. ANN. (Purdon, I93I) tit. I2, \$ 85; cf. Hasson v. Klee, I8I Pa. II7, 37 Atl. I84 (I897); Douglas v. Irvine, I26 Pa. 643, I7 At1. 802 ( I889). 
"No entry upon lands shall arrest the running of the statute of limitations, unless an action of ejectment be commenced therefor within one year thereafter; nor shall such entry and action, without a recovery therein, arrest the running of said statute in respect to another ejectment, unless it be brought within a year after the first shall have been nonsuited, arrested, or decided against the plaintiff therein."

The obvious effect of such a provision is to nullify practically the use of selfhelp. Wood in his Treatise on the Limitation of Actions ${ }^{104}$ refers to eleven other states as having a similar provision, and doubtless a close scrutiny of the statute books would disclose more. ${ }^{105}$

At least Michigan ${ }^{100}$ has a statute of the following nature:

"No person shall be deemed to have been in possession of any lands, . . merely by reason of having made an entry thereon, unless he shall have continued in open and peaceable possession of the premises for at least one [I] year . . . or unless an action shall be commenced upon such entry and seisin, within one [x] year after he shall be ousted or dispossessed of the premises."

The wording of a legislative enactment of this type bears close analogy to the English Act which in effect provides that "no person should be deemed to have been in possession of any land within the meaning of the Act merely by reason of having made an entry thereon." ${ }^{107}$ This class of American statutes by no means prevents self-help by "entry". But its more rigorous requirements pave the way for American courts, like the English, to construe it strictly against the owner.108 And perhaps the American addition of one year's continued, "open and peaceable possession" may be attributed to a desire to avoid the difficulties of proving possession in a country abounding in land and comparatively sparsely populated.

The third class of statute, which Tiffany says ${ }^{109}$ "expressly deprives the entry of any . . . effect" does so only by implication. For example, the Florida, ${ }^{110}$ Missouri, ${ }^{111}$ and Texas ${ }^{112}$ statutes by their wording give rise to the implication that self-help by "entry" can no longer be employed, reciting:

"No action for the recovery of real property, or for the recovery of the possession thereof, . . . shall be brought . . . ."

Instead of speaking in terms of "entry" reference is made to "action", which apparently implies a judicial proceeding as distinguished from self-help by "entry". Keeping in mind the apparent tendency of the courts to construe the statute strictly against the owner and the expressio unius exclusio alterius theory of statutory construction, the conclusion may well be reached that "entry" has been abolished.

Even more deterrent to the use of self-help than these statutes are the practically universal forcible entry enactments, applying both civil and criminal sanctions. It seems strange, to say the least, that self-help by "entry" should be indulged when such prohibitions exist. The usual type of penal statute makes it

104. Op. cit. supra note $15, \$ 270$.

I05. E. g., ARK. Dig. STAT. (Crawford \& Moses, Igar) $\$ 6944$.

106. Mich. Comp. Laws (Mason, I929) c. 266, § I397I.

I07. 3 \& 4 WMr. IV, c. $27, \S$ ro (1833).

I08. Cf. Place v. Place, I39 Mich. 509, I02 N. W. 996 (I905).

109. 2 TIFFANY, op. cit. note I, \& 507, at I956.

Iro. 2 FLA. COMP. GEN. LAWS, I927 (I928) § 4652.

III. I Mo. Rev. Stat. (I929) \$850.

II2. TEx. STat. (I928) tit. 91, arts. 5507-5519; cf. Cobb v. Robertson, 99 Tex. 138, I46, 86 S. W. 746, 749 (1905); Glover v. Pfeuffer, I63 S. W. 984 (Tex. Civ. App. rg14). 
unlawful for the dispossessed owner to retake possession of his land by force. ${ }^{113}$ And approval of self-help becomes a still less likely possibility when statutes defining "forcible entry" are discovered : ${ }^{114}$ "A forcible entry is an entry without the consent of the person having the actual possession."

Divergent results have been reached as to the effect of these "forcible re-entries". One view considers the Statute of Limitations uninterrupted by such an entry. ${ }^{115}$ Another denies the effect of the re-entry, at least when not followed by continuous possession. ${ }^{116}$ Still another demands the institution of a forcible entry action within a reasonable time by the adverse possessor who has been ousted, ${ }^{117}$ the inference being that if such action is not brought within that period the entry will be considered effective despite its forcible character. And finally there is the view that forcible entry is effective to toll the statute although the adverse claimant may regain possession by legal proceedings. ${ }^{118}$ The last result is logically correct, since "entry" represents the process of $O$ 's regaining possession of his land without judicial aid. But doubtless the underlying punitive sanctions make the other results persuasive.

Thus the numerous statutory modifications of "entry" almost close the door to the exercise of this form of self-help. And the forcible entry statutes, where they are not interpreted to prevent an effective entry, are at least so great a deterrent as practically to abolish it. It is a paradox, to say the least, for $O$ to have a right of entry, and yet be subject to civil liability or criminal punishment, or both, should he exercise it.

\section{In Conclusion}

Judicial and legislative disapproval of self-help by "entry" is at least inferentially apparent from this study. Indeed, strong doubt exists as to whether this remedy is either theoretically or practically possible. No sensible lawyer would prefer "entry" to ejectment as a means of preventing the ripening of adverse possession into title. Nevertheless, the rules of the systematic doctrine of "entry" continue to find futile expression.

M. P.R.

ir3. Conn. Gen. Stat. (Revision of I930, Vol. II) $\S 5889$.

II4. ARIz. Rev. CoDe (I928) \$ 4312. "In Illinois an entry has been regarded as forcible for this purpose if against the will of the person in possession." 2 TIFFANY, op. cit. supra note I, $\S 50 \%$, at 1956, n. I6; Bugner v. Chicago Title \& Trust Co., 280 II1. 620, II7 N. E. 7II (I9I7).

II5. Cf. Gould v. Carr, 33 Fla. 523, 15 So. 259 (I894); Horton v. Smith-Richardson Investment Co., 8I Fla. 255, 87 So. 905 (Ig2I) ; Bugner v. Chicago Title \& Trust Co., 280 Ill. 620 , II7 N. E. 7II (I9I7); Nelson v. Johnson, 189 Ky. 8I5, 226 S. W. 94 (Ig20); Donovan v. Bissell, 53 Mich. 462, I9 N. W. 146 (1884); Norvell v. Gray, I Swan 96 (Tenn. I85I). II6. City of Pella v. Scholte, 24 Iowa 283 (I868) semble at 294; 2 TIFfany, op. cit. supra note $\mathrm{x}, \S 507$, at 1956 , and cases cited in $\mathrm{n}$. $\mathrm{I} 6$.

I17. Cf. Ladd v. Dubroca, 6I Ala. 25, 29 (1878) ; Ferguson v. Bartholomew, $67 \mathrm{Mo.}$ 212 (1877) ; Cary v. Edmonds, 7I Mo. 523 (1880); Duncan v. Gragg, 242 S. W. 491 (Tex. Civ. App. I922) ; SEDGWICK AND WAIT, op. cit. supra note 2, \$ 742, at 589; 2 Wood, op. cit supra note $15, \$ 270$, at 1306 .

II8. City and County of San Francisco v. Fulde, 37 Cal. 349, 353 (I869): "It makes no difference by whom, or in what manner, the continuity of the adverse possession is broken, so only that it is broken." Cf. 3 THompson, op. cit. supra note I, \$2529, and case cited in n. 28: "If the possession be interrupted, either by fraud or force, or by process of law, the statute begins to run only from the time of re-entry " HEwitT, A TREATISE ON THE STATUTES OF LIMITATIONS (I893) I66. However, in the converse situation where by force or fraud of the adverse possessor the owner is prevented from making an "actual entry" on his land, at least one text-writer states that "his intent to do so, declared as near the land as possible, is equivalent to an actual entry." ANGETI, op. cit. supra note I3, $\$ 377$, at 382 . But Trickett's interpretation of Malson v. Fry, I Watts 433 ( $\mathrm{Pa}, \mathrm{r} 833$ ) is that the "efforts of the owner to get upon his land and resume possession, defeated by the threats or violence of the intruder, are not equivalent to an entry, and will not prevent the latter's acquiring a title in twenty-one years." TRICKETr, op. cit. sipra note 3 , \$ II7, at I57. 